\title{
Review on Microbial Degradation of Aromatic Hydrocarbons: Focus on Kinetics Modelling
}

\author{
Umar, Z.D. (iD and Yunusa, Y.R. \\ Department of Microbiology, Umaru Musa 'Yar'adua University, Katsina, Nigeria. \\ *Corresponding Author: zubairu.umar@umyu.edu.ng; +234(0)7063966453
}

\section{Abstract}

Many anthropogenic activities produce huge quantities of chemical pollutants that find their ways into the natural environment. Those chemicals can either be of organic or inorganic sources, depending on their originating compounds. Over the years, there had been research findings regarding the application of microorganisms to provide solutions in the environment. This becomes imperative as salient issues in researches on microbial bioremediation will be understood. This review focused more on Kinetics modeling during biodegradation of aromatic hydrocarbons and their nature and effect on the environment coupled with the conventional remediation techniques. Kinetics modeling during bioremediation predicts microbial activities through their mechanism of actions towards the targeted contaminants. This gives better understanding of the rate of chemical degradation through different variable parameters. Modeling the cultivation of degrading organisms can highlight the inhibitory properties of the cells involved. Therefore, specific microbial growth rates can be modeled at various initial concentrations of the involving substrates. Such could be achieved using secondary models of Monod, Teissier, Aiba, Haldane, Yano and Luong. The models can reveal the substrate inhibitory effects to the reduction rate (as in the case of Monod) or inhibitory to the substrate rates like in the other models. Many studies were recently conducted on modeling microbial growth. Hence, utilization of those models are the best evidence that indicate when the substrates are toxic or inhibitory to the microbes. This provides better understanding on the future researches regarding the bioremediation effectiveness on scientific arguments.

Keywords: Environment, Pollutants, Microorganisms, Remediation, Modeling
\end{abstract}

\section{INTRODUCTION}

Environmental pollutants constitute large group of hazardous chemicals, which can be naturally occurring or from anthropogenicsource.Among the contributors from natural sources are oil seepage, forest fires and volcanic eruptions while anthropogenic sources involved industries, automobile discharges, incineration, coal, petroleum, agricultural practices and domestic wastes (Ravindra et al., 2008). These sources deposit toxic organic and inorganic pollutants into the environment, many of which persist for a long duration because of their chemical complexity (Maliszewska, 1999). The persistence contributes immensely in the bioaccumulation of the pollutants within different ecosystems (Arulazhagan and Vasudevan, 2011). A certain proportion of the pollutants undergo natural transformations while others posedserious environmental challenge that critically affects public health (Bispo et al., 1999; Lundstedt et al., 2007; Yunusa and Umar, 2021).

The highest quantities of such organic materials are obtained from petroleum fractions
Among the organic pollutants, are aromatic compounds that constituted assembled carbon structures in different benzene rings (Mishra et al., 2001; Rubio-Clemente et al., 2014; Umar, 2017). The complexity of these structures can be attributed to stable resonance within the conjugated $\pi$-electrons of the inert nucleus which allows them resist microbial degradation processes (Johnsen and Karlson, 2005; Desai and Vyas, 2006). The structure of aromatic compounds with single ring like phenol is simpler than those with many rings (Van Hamme et al., 2003). Polycyclic aromatic compounds have low solubility in water but are readily soluble in fatty materials, which allowed them to be highly accumulative within animal's fatty cells thereby inducing mutation and cancer (Brandt and Watson, 2003). Many aromatic compounds are produced through incomplete combustion of organic matter and deposited into the environment through anthropogenic practices (Wong et al., 2004; Chung et al., 2007; IARC, 2010). thatrequired higher temperatures of refining (Connell, 2005). Many aromatic compoundscan 
cause animal skin photosensitization associated with mild allergy, neurological disorders, kidney damage and body weight reduction (Patriet al., 2010).

Incidences of environmental pollutionsweredue to industrialization, transportation, minerals prospecting, refining, usage (Sany et al., 2014; Keshavarzifard and Zakaria, 2015; MohdRadzi et al., 2016). Public health related challenges are faced as a result of the frequency of the pollution occurrences and their severity to living ecosystems (Spinelliand Freitas, 2005; Akintunde et al., 2015). High molecular weights polycyclic aromatic hydrocarbonsfor instance affect human life through the skin absorption into the bloodstream that eventually became converted into electrophilic derivatives that may result in cancer (Yunusa and Umar, 2021). This may affect the central nervous system through the blood circulation and causes peripheral neuropathy, and paralysis (Yunusa and Umar, 2021). The post-disposalbehavior of such pollutants gave further complications as unintended habitats are grossly affected (Oa and Lee, 2009; Park et al.,2010).

Microbial removal of environmental pollutants is reported to be the best technique due to the complete metabolic removal being associated with less expensive technology (Abdulsalam and Omale, 2009; Karamalidiset al., 2010). In this process, naturally occurring microbial cells are utilized because of their abundance, diversity, catabolic versatility and adaptations to critical conditions (Moraeset al., 2009). Bacteria are among the frequently utilized organisms as they can occupy suitable habitats in different environments as a result of them possessing broad enzymes spectrum that enables them catabolize the compounds as major substrates (Madigan et al., 1998). Such groups of organisms include the commonly studied bacteria like Mycobacterium, Arthrobacter, Burkholderia, Sphingomonas, and Pseudomonas (Kim et al., 2003; Seo, 2006; Baboshin et al., 2008).

There are instances where the environment is found to be contaminated with complex mixtures of both organic and inorganic pollutants like aromatic hydrocarbons and hazardous heavy metals. In such situations, microorganisms may face difficulties in removing such pollutants due to the challenges in transporting the organic pollutants into the microbial cells for mineralization resulting from the inhibitory effects of the heavy metals (Sandrin and Maier, 2003; Pereira et al., 2007; Srogi, 2007; Cao et al., 2008; Ibarrolaza et al., 2009). The heavy metals usually alter the structural permeability of the microbial cell membranes and prolong the cells' acclimatization time before consuming the organic substrate (Maliszewska and Smreczak, 2003; Sandrin and Maier, 2003; Zhang et al., 2011; Bashir et al., 2014). This makes the pollutants to inhibit the microbial growth by substituting the main enzymes' functional groups with heavy metals ions (Yunusa and Umar, 2021).

Therefore, before initiating bioremediation of contaminated environments via the use of microorganisms, it is important to perform exhaustive background checks on the intrinsic features of the contaminated sites. Such an investigation should involve the elucidation of the extent of contaminated area, sampling parameters, locations, collection procedures and analytical methods to be used (Umar and Bashir, 2014).

The release of organic and inorganic pollutants allows their widespread into various soil, air and water environments (Umar, 2017). Within the water environment, hazardous chemicals attach themselves to the suspended particles before settling down the sediments and entering the food chain of the ecosystem (Rubio-Clemente et al., 2014). Once deposited in the soil environment, such pollutants became adsorbed to the soil particles with a very minute quantity being dissolved and transported into surface water and down the groundwater via runoff (Bossert and Bartha, 1984; Zhang et al., 1998; Birgül et al., 2011; Vela et al., 2012; Chizhova et al., 2013).

\section{STRATEGIES FOR REMEDIATING ENVIRONMENTAL POLLUTANTS Physical removal approach}

$>$ Adsorption:This involved attaching the aromatic compoundsinto the adsorbentdue to surface energy (IUPAC, 1990). The other atoms in the surface of the adsorbents through physio-sorption, van der Waals attraction, and chemio-sorption or electrostatic attraction fill bonding requirements of the constituting atoms (Ferrari et al., 2010). Adsorption can be applied to activated charcoal, and water purification processes through the selective transfer of adsorbates from the fluid phase to the surface of insoluble, rigid particles suspended in a vessel or packed in a column (Czelejet al., 2016). Materials employed as adsorbents are spherical pellets moldings or monolithshaving the capacity to resist abrasion and thermal stability. Adsorbents can also be hydrophilic, polar, oxygencontaining compounds such as silica gel and zeolites (Cussler, 1997). 
$>$ Photolysis: This involved photon-mediated breakdown of the aromatic compounds due to mixed chemical interactions which results in the photodecomposition of the targeted contaminants (Thyrhaug et al., 2016). The source of the photon need not only be visible light as all photons have enough energy that can interfere with chemical bonds. The reactions involve electromagnetic wave energy equivalent to or greater than those of visible light, as a photon's energy is inversely proportional to its wavelength. Thus, Ultraviolet light, $x$ rays, gamma rays and visible light itself can bring about photolysis (Thyrhaug et al., 2016). Hence, photolysis is utilized in remediating contaminated environments by applying those radiations to breakdown pollutants molecules.

> Ozonation: The process can be utilized during the precipitation of iron and manganese from water and detoxifications of urea and cyanides to cyanates (Horvath et al., 1985). Recent advances elucidate the effects of acute and chronic ozone exposure on human health (EPA, 2015). Among such effects include the impairment of the respiratory, cardiovascular and central nervous systems which may lead to premature death and problems in human reproductive health and development (EPA, 2015).

Degradation of Petroleum hydrocarbons

Bioremediation can completely transform pollutants into non-hazardous products with fewer effects in an environmentally friendly manner (Declercq et al., 2012). This review gives much emphasis on organic pollutants as they constituted larger percentage of the entire global pollutants that destabilize living ecosystems (Umar et al., 2016; 2017; 2018a; 2018b; 2019; 2020a; 2020b). Additionally, many inorganic pollutants are degraded through the physicochemical approaches as explained in the above paragraphs. Many organic structures are susceptible to enzymatic attacks which are simply obtainable from microorganisms (Yunusa and Umar, 2021). The microorganisms involved required nutrient sources and other favorable culture conditions to convert the target pollutant within the cellular biomass into an intermediate and metabolic precursor (Yunusa and Umar, 2021). The process had been reported since $19^{\text {th }}$ century, but further researches could provide broad perspectives into the matter (Borden et al., 1986). Recognition of the target substrate by the aerobic microbes is aided by the enzymes and facilitated by chemical transformations thorough hydroxylation (Desai and Vyas, 2006). Anaerobic microbes on the other hand, can only reduce the target substrate bonds thereby simplifying its complexity nature (Desai and Vyas, 2006).

The commonly removal approach of polycyclic aromatic hydrocarbons involved the oxygenation of the targeted compound into dihydrodiol intermediate with the help of dioxygenase enzymes (Mishra et al., 2001). The process involved the initial activation of the enzymes using NADPH or NADP co-factor which increases their reactivity and makes the targeted substrate lose their resonance stability. This allowed the aerobic organisms attach the oxygen molecules onto the targeted organic structure and make them less complex for the subsequent utilization by the microbes as carbon source (Mishra et al., 2001). Further hydroxylation breaks the pollutant structure into the products that can enter the tricarboxylic acid (TCA) cycle and produce adenosine tri phosphate (ATP) energy for the cells functioning (Umar, 2017). The end product is usually water and carbon dioxide for plants utilization (Khanna et al., 1998).

\section{Mechanisms of Microbial actions during}

\section{Biodegradation}

Metabolites recognition during biodegradation provides better understanding on the cellular metabolic pathways and dynamics approach undergone by the microbes involved (Kitano, 2002; Goodacre et al., 2004; Nicholson et al., 2004; Tao et al., 2007; Lu et al., 2014). For instance, during the biodegradation of phenanthrene, intermediates called 3,4dihydroxyphenanthrene and phthalic acid are produced through dioxygenation of $\mathrm{C}_{3}$ and $\mathrm{C}_{4}$ (Umar et al., 2016; 2017; 2018a; 2018b). The TCA cycle is the ultimate destination of those products, and its byproducts are thought to be beneficial (Seoet al., 2009). The most commonly bacteria involved are members of the gramnegative group of the genera Pseudomonas, Alcaligenes, Acinetobacter, Arthrobacter, Mycobacteria and Sphingomonas, to Corynebacterium, Rhodococcusand Nocardia (Ahn et al., 1999; Stingley et al., 2004). Recent researches had shown that genus Enterobacter is very efficient in degrading aromatic structures (Umar et al., 2016; 2018a; 2018b). The bacteria are rampantly prevalent on used vehicle lubricants contaminated soil with population size up to $10^{8}$ cells/gram (Umar et al., 2016).

The mechanisms through which these organisms performs their functions involved bonds breakage at the meta-position (extradiol 6 cleavage), or at the ortho-position (intradiol 
cleavage) of the targeted compound (Mishra et al., 2001). Intradiol cleavage involved hydroxylation of carbon atoms while extradiol cleavage involved the adjacent carbon atoms hydroxylation (Mishra et al., 2001). In the extradiol cleavage, catechol 2,3-dioxygenase, 1,2-dihydroxynaphthalene dioxygenase and 2,3dihydroxybi-phenyl dioxygenase are encoded by the nahH, nahC and BphCs genes respectively (Harayama and Rekik, 1989). Each of those enzymes possessed four matching subunits of 32 $\mathrm{kDa}$ with $\mathrm{Fe}^{2+}$ cofactor (Kimbara et al., 1989; Hirose et al., 1994). The expression of aa, $a B$ and $B B$ subunits within catechol 1,2dioxygenases is thought to confer on bacteria ability to efficiently carryout intradiol cleavage (Nakai et al., 1990).

KINETICS MODELING

Different models were used to describe biodegradation of organic pollutants which provide better degradation understanding (Loginova et al., 2009). In this approach, microbial growth rate would be associated with the concentration of the organic substrate. Numerous mathematical models (primary) have been put forward to explain the microbial growth and metabolism of the substrates (Loginova et al., 2009). Microbial growth usually exhibits a known pattern, in which the specific growth rate starts initially at zero at a lag time $(\lambda)$, followed by the exponential phase, where an acceleration in a certain time period leads to a maximal value for the growth rate $\left(\mu_{\max }\right)$. The growth curves eventually plateau entering a stage of which the rate becomes zero, where an asymptote $(A)$ is normally achieved in form of stationary phase. Eventually, in the death phase, the growth rate becomes negative (Zwietering et al.,1990). The lag period is thought to occur as the bacteria prepared for growth after acclimatizing to their new environment (Baranyi and Roberts 1994). In secondary modeling, $\mu_{\max }$ helps in determining the effects of both dependent and independent parameters as microbial activity $\left(\mu_{m}\right)$ equalizes the slope of the line at the exponential phase (Zwietering et al.,1990; Fujikawa, 2010). The most studied method involved the sigmoidal curve and linear regression while nonlinear regression can be used to describe the entire set of data producing constants such as $\mu_{\max }, \lambda$ and $A$ (Johnsen et al.,2013). Primary Equations involving Logistic (Zwietering et al.,1990), Gompertz (Gompertz, 1825), Richards (Richards, 1959), Schnute (Zwietering et al.,1990), Baranyi-Roberts (Baranyi, 1995), Von Bertalanffy (Babák et al., 2012), Buchanan three-phase (Buchanan, 1993) and Huang (Huang, 2013) are the primary kinetics modeling (Equations 1 to 8 ).

$$
\begin{aligned}
& \text { Modified Logistic } \quad=\quad y=\frac{A}{\left\{1+\exp \left[\frac{4 \mu_{m}}{A}(\lambda-t)+2\right]\right\}} \\
& \text { Modified Gompertz } \quad=\quad y=A \exp \left\{-\exp \left[\frac{\mu_{m} e}{A}(\lambda-t)+1\right]\right\} \\
& \text { Modified Richards } \left.\quad=\quad y=A\left\{1+v \exp (1+v) \exp \left[\frac{\mu_{m}}{A}(1+v)\left(1+\frac{1}{v}\right)(\lambda-t)\right]\right\}\right\}^{\left(\frac{-1}{v}\right)} \\
& \text { Modified Schnute } \quad=\quad y=\left(\mu_{m} \frac{(1-\beta)}{\alpha}\right)\left[\frac{1-\beta \exp (\alpha \lambda+1-\beta-\alpha t)}{1-\beta}\right]^{\frac{1}{\beta}} \\
& \text { Baranyi-Roberts }=\quad y=A+\mu_{m} x+\frac{1}{\mu_{m}} \ln \left(e^{-\mu_{m} x}+e^{-h_{0}}-e^{-\mu_{m} x-h_{o}}\right) \text { or } \\
& -\ln \left(1+\frac{e^{\mu_{m} x+\frac{1}{\mu_{m}} \ln \left(e^{-\mu_{m} x}+e^{-h_{0}}-e^{-\mu_{m} x-h_{0}}\right)}-1}{e^{\left(y_{\max }-A\right)}}\right)
\end{aligned}
$$

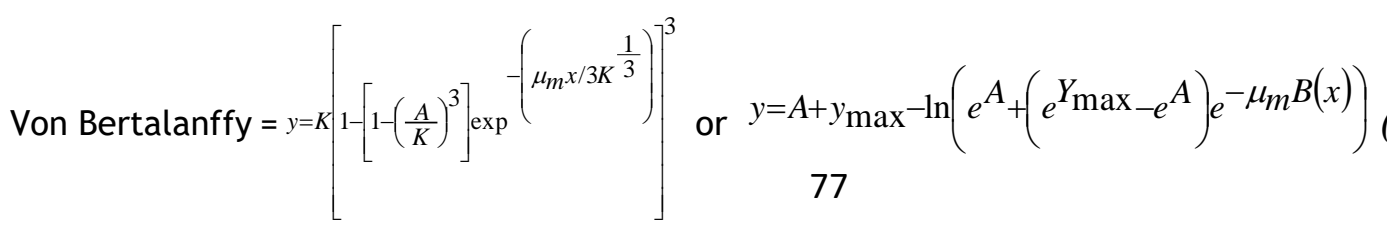


Huang

$$
\begin{gathered}
=\quad B(x)=x+\frac{1}{\alpha} \ln \frac{1+e^{-\alpha(x-\lambda)}}{1+e^{\alpha \lambda}} \\
\mathrm{y}=\mathrm{A}, \text { if } \mathrm{x}<\operatorname{lag} \\
\mathrm{y}=\mathrm{A}+k(\mathrm{x}-\lambda), \text { if } \lambda \leq \mathrm{x} \geq x_{\max }
\end{gathered}
$$

Where

A isthe microbial growth lower asymptote

$\mu_{m}$ is the maximum specific bacterial growth rate

$v$ is the effect near which asymptote maximum bacterial growth occurs

$\lambda$ is the period involved in the microbial lag phase

$y_{\max }$ is themicrobial growth upper asymptote

$\mathrm{e}$ is the exponent $(2.718281828)$

tis the sampling time

$a, B, k$ are the curve fitting parameters

$h_{0}$ is the dimensionless parameter quantifying the initial state of the degradation.

Kinetics modeling will enhance specific microbial growth rate as theoretical maximum growth is achievable whether the lag period changes or not. Likewise, modeling results can highlightinhibitory properties, if any, of growth at high concentrations, as was demonstrated by several workers (Al-Darbi et al., 2005; Campo et al.,2007). Then, it is possibleto model specific growth rates at various initial concentrations of the substrate using different secondary models (Equations 9 to 15). Such are the specific secondary model equations used during biodegradation of organic pollutants.Secondary modeling can also reveal whether the substrate is not inhibitory to Monod

Haldane

$$
=\mu_{\max } \frac{S}{K_{s}+S}
$$

reduction rate (Monod) or if it is inhibitory to the rates (Haldane, Teissier, Aiba, Yano and Luong). Multiple researches had been conducted on modeling microbial growth on lipid rich substrates using the classical Monod kinetics (Nwekeet al.,2014; Nkeiruka and Tagbo, 2014). The utilization of those models in thereduction kineticis the best evidenced that substrates are toxic or inhibitory to the microbes (Mercurio et al.,2004; Saifuddin and Chua 2006). The Haldane models has been utilized in modeling hydrocarbon degradation and this is understandable as hydrocarbons are toxic(Ahmad et al.,2014).

Teissier

$$
=\mu_{\max } \frac{S}{S+K_{s}+\frac{S^{2}}{K_{i}}}
$$

Aiba

$$
=\mu_{\max }\left(1-\exp \left(-\frac{S}{K_{i}}\right)-\exp \left(\frac{S}{K_{s}}\right)\right)
$$

Yano and Koga

$$
=\mu_{\max } \frac{S}{K_{s}+S} \exp \left(-K_{p} P\right)
$$

$$
=\frac{\mu_{\max } S}{S+K_{s}+\left(\frac{S^{2}}{K_{1}}\right)\left(1+\frac{S}{K}\right)}
$$

Han and Levenspiel

$$
=\mu_{\max }\left[1-\left(\frac{S}{S_{m}}\right)\right]^{n}\left[\frac{S^{78}}{S+K_{s}\left(1-\frac{S}{S_{m}}\right)^{m}}\right]
$$


Luong

$$
=\mu_{\max } \frac{S}{S+K_{s}}\left[1-\left(\frac{S}{S_{m}}\right)^{n}\right]
$$

Where

$\mu_{\max }$ is the maximal growth rate $\left(\mathrm{h}^{-1}\right)$

$K_{s}$ is the half saturation constant for maximal reduction

$S_{m}$ is the maximal concentration of substrate tolerated

$\mathrm{m}, \mathrm{n}, \mathrm{K}$ are the curve parameters

Sis the substrate concentration

$P$ is the end product concentration

Assessment of the best models, for both primary and secondary modeling can be achieved using the statistical tests involving root-mean-square error, adjusted coefficient of determination $\left(R^{2}\right)$, bias factor, accuracy factor and corrected Akaike Information Criterion (Halmi et al.,2014). Increasingorganic substrates concentrations without optimization cells population as the experiment progresses signified the accumulation of toxicants to the microbial cells (AbdEl-Mongy et al.,2015). Such toxicants might include aromatic and halogenated hydrocarbons, phenolics, pesticides, and dyes which forces the microbial growth to be severely retarded at higher concentrations. Glucose is apparently a harmless substrate, but studies indicated that higher concentrations greater than $105 \mathrm{w} / \mathrm{v}$ can inhibit its oxidation in aerobic batch microbial culture (Misenheimeret al.,1965). Monod model can be less effectivedue to substrate-inhibition to microbial cells. Therefore, microbial growth inhibition due to substrate higher concentrationis a derivative ofMonod kinetics model. This can beimprovedthrough the $\mathrm{Ki}$ constant as the unstructured models are strongly recommended to describe the hyperbolic curve of microbial growth under substrate inhibition. Hence, Haldane-Andrews (Haldane), Teissier-Edwards (Teissier), Aiba, Yano and Koga, Han and Levenspiel and Luong models are the best to handle experiments ofmore than two parameters.

Equations 9 to 15 were developed from the theory of enzyme inhibition as the equation 10 was the first to be applied during kinetics of microbial inhibition(Knowles et al., 1965). In these equations, enzyme inhibition is explained by more than two substrate moleculesthat formed inactive complex. Excess nitrite inhibition to Nitrobacter winogradskyi growth was successfully explained by model of the equation 10(Kornegay and Andrews, 1968). The equation is modified to assume the existence of two different inactive forms of substrateenzyme complexes.

Another classic model used in microbial population growth is the Gompertz function
(Quintas et al., 2007). Initially, this model was used in actuarial science for appropriate human death data, but as time goes, it was applied to model organ growth, deterministically(Okpokwasili and Nweke, 2006). Improvements in the Gompertz function have allowed designing models that candescribe the influences of inherent elements such as temperature and availability of oxygen on microbial growth factors. This model thrives on the exponential relationship between specific growth rate and population density, and had been used quite recentlyto model bacterial growth on hardy substrates(Haji et al., 2011; Salam et al.,2012).

Similarly, Kim et al. (2005)used the product inhibition model to model the kinetics of various substrate inhibition through the introduction of another dimensionless constant $(\mathrm{K})$. However, values of the dimensionless constant $(K)$ are very large, thus, the first two equations are thought not suitable for modeling. Furthermore, Edwards' and HaldaneAndrew's equations are said to be statistically indistinguishable from each other, and, a comparison of the fit to the growth data of various organisms how no significant differences between the models (Tseng and Wayman, 1975). Nonetheless, as regards the Monod and Andrews functions, it is possible to consider the circumstances in which utilization of these models might cause inaccurate outcomes, even though the models suitablyexplain the consequences of substrate concentration on the growth of microorganisms. This is often true when the substrates are toxic xenobiotic,leading to inhibition of growth (Kulkarni and Chaudhari, 2006). Tackling this issue birthed the development of a number of inhibition models, including the Teissier, Luong and Han and Levenspiel models that directly ascribing the abovementioned characteristic 9 (Schröder et al., 1997). The Teissier/Tessier Model studies the effects of substrate diffusion on bacterial growth kinetics through the bacterial outer membrane (Şeker et al.,1997). Contrastingly, the Monod model studies the single rate-limiting effect and saturation UMYU Journal of Microbiology Research www.ujmr.umyu.edu.ng 
kinetics of substrate transport through the cytoplasmic membrane (Monod, 1949).

A similarity exists between the Tessier equation and the Edward model. The Edward model combines the mechanism of diffusion-controlled substrate supply of the Tessier model with a shielding diffusional control of high concentrations. Sabullah et al. (2016) successfully used the Tessier model in modeling bacterial reduction of molybdenum, likewise Tavassoli et al., (2012) used it to model bacterial growth on asphaletes. Further studies were done on biopolymers, phenol, and other substrates using the same model (Agarry et al., 2009). Other models such as the discontinuous models of, are tripartite, including exponential, stationary, and decay phases (Tseng and Wayman, 1975). In this model, growth inhibition doesn't exist below a threshold substrate concentration, like other models; as such, when a substrate concentration exceeds a particular level, the microbial growth level decreases in proportion to the concentration difference. Tseng and Wayman (1975) used this model to successfully model the kinetic data of two bacteria growing on butanol and methanol, which are Pseudomonas methanica and Arthrobacter AK19. The model applied in describing toluene degradation (Choi et al., 2008).

The models of Luong and Han and Levenspiel are understood to be more effective than that of Tseng and Wayman models (Mulchandani and Luong, 1989). However, the integration of an exponential delay function in the Han and Levenspiel model, leads to the matching of the inflection point on the growth curve to a particular product concentration (Mulchandani and Luong, 1989). The Han and Levenspiel model has been readily applied, and it had been successful in modeling the growth of microorganisms on the congo red, solid waste, phenol, and m-cresol (Poggi-Varaldo et al., 1997; Saravanan et al., 2008; Bajaj et al.,

\section{REFERENCES}

Agarry, S., Audu, T., Solomon, B. (2009). Substrate inhibition kinetics of phenol degradation by Pseudomonas fluorescence from steady state and wash-out data. International Journal of Environmental Science and Technology:(IJEST), 6, 443.

AbdEl-Mongy, M.A., Shukor, M.S., Hussein S, Ling A.P.K., Shamaan N.A, Shukor. M.Y. (2015) Isolation and characterization of a molybdenum-reducing, phenol- and catechol-degrading Pseudomonas putida strain amr-12 in soils from Egypt. Research Chemistry \& Chemical
2009; Gopinath et al., 2011). This had successfully modeled bio-hydrogen production and had accurately modeled microbial growth at high salt concentrations( Wang and Wan, 2008).

Luong developed a continuous version of the Han and Levenspiel model through the adaptation of the nonlinear product inhibition (Mulchandani and Luong, 1989). The proposed model is capable of describing both limiting effect of substrate to growth at low concentration, which is a Monod model, and the inhibiting effect of substrate to growth at high substrate concentrations. The model moreover introduced a parameter for the maximum substrate concentration, and the growth completely ceases above this constant value (Mulchandani and Luong, 1989). The model had been employed suitably in the growth of microorganisms on phenol, caffeine, ammonia, monochlorobenzene and 1,2dichloroethane (DCE), 2fluorophenol, dichloromethane, formaldehyde, $\mathrm{m}$-cresol, 4-fluorocinnamic acid and methyl isobutyl ketone (Saravanan et al., 2008; Raghuvanshi et al., 2012).

\section{CONCLUSION}

The use of microbial consortia is the best approach for biodegradation, as groups of microorganisms possess greater enzymatic capabilities than single strains. A variety of primary and secondary models exist that described microbial growth during biodegradation and its inhibition. Understanding these concepts will enable us in critically appreciating what contributions have been made in the past, learning what is currently being done and anticipating what needs to be done in the future. This will appreciate the current scientific effort and anticipates safer environmental future for the entire

humanity.

Ahmad, S.A., Ahamad, K.N.E.K., Johari, W.L.W., Halmi, M.I.E., Shukor, M.Y., Yusof, M.T. (2014). Kinetics of diesel degradation by an acrylamidedegrading bacterium. Rendiconti Lincei 25, 505-512.

80

Engineering, Biotechnology, Food Industry 16, 353-369.

Al-Darbi MM, Saeed NO, Islam MR, Lee K (2005) Biodegradation of natural oils in seawater. Energy Sources27, 19-34. doi:10.1080/00908310490448073. 
Akintunde, W. O., Olugbenga, O. A., and Olufemi, O. O. (2015). Some Adverse Effects of Used Engine Oil (Common Waste Pollutant) On Reproduction of Male Sprague Dawley Rats. Open access Macedonian Journal of Medical Sciences, 3(1), 46.

Ahn, Y., Sanseverino, J., and Sayler, G.S. (1999). Analyses of polycyclic aromatic hydrocarbon-degrading bacteria isolated from contaminated soils. Biodegradation10(2), 49-157.

Arulazhagan, P., and Vasudevan N. (2011). Biodegradation of PAHs by halotolerant bacterial strain Ochrobactrumsp. VA1. Marine Pollution Bulletin, 62(2), 388394.

Abdulsalam, S., and Omale, A.B. (2009). Comparison of biostimulation and bioaugmentation techniques for the remediation of used motor oil contaminated soil. Brazilian Archives of Biology and Technology 52(3), 747-754.

Babák L, Šupinová P, Burdychová R (2012) Growth models of Thermus aquaticus and Thermus scotoductus. Acta Universitatis Agriculturae et Silviculturae Mendelianae Brunensis. 60 , 19-26. doi:10.11118/actaun201260050019.

Baranyi, J., Roberts, T.A. (1994). A dynamic approach to predicting bacterial growth in food. International Journal of Food Microbiology 23, 277-294.

Baranyi J (1995) Mathematics of predictive food microbiology. International Journal of Food Microbiology26, 199-218. doi:10.1016/0168-1605(94)00121-L.

Bashir, A., Umar, Z.D., and Steve, J.O. (2014): Comparative analysis of Pneumosiderosis among different metal workers in Malumfashi, Katsina, Nigeria. International Journal of Scientific and Engineering Research, 5(6): 1429-1436.

Buchanan RL (1993) Predictive food microbiology. Trends in Food Science and Technology. 4, 6-11.

Borden, R.C., Bedient, P.B., Lee, M.D., Ward, C.H., and Wilson, J.T. (1986). Transport of dissolved hydrocarbons influenced by oxygen limited biodegradation: application. Water

Field Research, 22(13), 1983-1990.

Bajaj, M., Gallert, C., \& Winter, J. (2009). Phenol degradation kinetics of an aerobic mixed culture. Biochemical Engineering Journal, 46, 205-209.
Birgül, A., Tasdemir, Y., and Cindoruk, S.S. (2011). Atmospheric wet and dry deposition of polycyclic aromatic hydrocarbons determined using a modified sampler. Atmospheric Research, 101(1), 341-353.

Bossert I., and Bartha, R. (1984). The Fate of Petroleum in Soil Ecosystem: In Atlas, R.M. (Ed.) Petroleum Microbiology. Macmillan Publishing Company, USA, 435-473.

Baboshin, M., Akimov, V., Baskunov, B., Born, T.L., Khan, S.U., and Golovleva, L. (2008). Conversion of polycyclic aromatic hydrocarbons by Sphingomonas sp. VKM B2434. Biodegradation, 19(4), 567-576.

Brandt, H.C.A., and Watson, W.P. (2003). Monitoring human occupational and environmental exposures to PAHs. The Annals of Occupational Hygiene, 47(5), 349-378.

Bispo, A., Jourdain, M.J., and Jauzein, M. (1999). Toxicity and genotoxicity of industrial soils polluted by PAHs. Organic Geochemistry, 30(8), 947-952.

Chizhova, T., Hayakawa, K., Tishchenko, P., Nakase, H., and Koudryashova, Y. (2013). Distribution of polycyclic aromatic hydrocarbons in northwestern part of Japan Sea. Deep Sea Research Part II: Topical Studies in Oceanography, 86, 19-24.

Cao, L., Shen, G., and Lu, Y. (2008). Combined effects of heavy metal and PAHs on soil microorganism communities. Environmental Geology, 54(7), 1531-1536.

Choi, N.-C., Choi, J.-W., Kim, S.-B., \& Kim, D.J. (2008). Modeling of growth kinetics for Pseudomonas putida during toluene degradation. Applied microbiology and biotechnology, 81, 135-141.

Campo, P., Zhao, Y., Suidan, M.T., Venosa, A.D., Sorial, G.A. (2007).

81 Biodegradation kinetics and toxicity of vegetable oil triacylglycerols under aerobic conditions. Chemosphere, 68, 2054-2062.

Connell, D.W. (2005). Basic Concepts of Environmental Chemistry. CRC Press, 33487-2742.

Chung, M.K., Hu, R., Cheung, K.C., and Wong, M.H. (2007). Pollutants in Hong Kong soils: Polycyclic aromatic hydrocarbons. Chemosphere, 67(3), 464-473.

Cussler, E. L. (1997). Diffusion: Mass Transfer in Fluid Systems. 2nd edition. New 
York, USA: Cambridge University Press, pp. 308-330.

Czelej, K., Cwieka, K. and Kurzydlowski, K.J. (2016). $\mathrm{CO}_{2}$ stability on the $\mathrm{Ni}$ lowindex surfaces: Vander Waals corrected DFT analysis. Catalysis Communications, 80(5): 33-38

Desai A., and Vyas, P. (2006). Petroleum and Hydrocarbons Microbiology: Applied Microbiology. Report from the Department of Microbiology, MS University of Baroda, Vadodara India, 122.

Declercq, I., Cappuyns, V., and Duclos, Y. (2012). Monitored natural attenuation of contaminated soils: state of the art in Europe-a critical evaluation. Science of the Total Environment, 426, 393405.

Environmental Protection Agency of the United States, EPA (2015). Health Effects of Ozone Pollution. Available at https: / /www.epa.gov/ground-levelozone-pollution/health-effects-ozonepollution, accessed $19^{\text {th }}$ January, 2020.

Ferrari, L., Kaufmann, J., Winnefeld, F. and Plank, J. (2010). Interaction of cement model systems with superplasticizers investigated by atomic force microscopy, zeta potential, and adsorption measurements. Journal of Colloid Interface Sciences, 347(1): 1524.

Fujikawa H (2010) Development of a new logistic model for microbial growth in foods. Biocontrol Science15, 75-80. doi:10.4265/bio.15.75.

Gopinath, K. P., Kathiravan, M. N., Srinivasan, R., \& Sankaranarayanan, S. (2011). Evaluation and elimination of inhibitory effects of salts and heavy metal ions on biodegradation of Congo red by Pseudomonas sp. mutant. Bioresource technology, 102, 3687-3693.

Goodacre, R., Vaidyanathan, S., Dunn, W.B., Harrigan, G.G., and Kell, D.B. (2004). Metabolomics by numbers: acquiring and understanding global metabolite data. Trends in Biotechnology, 22(5), 245-252.

Gompertz, B. (1825). On the nature of the function expressive of the law of human mortality, and on a new mode of determining the value of life contingencies.

Haji, S., Benstaali, B., Al-Bastaki, N. (2011). Degradation of methyl orange by $\mathrm{UV} / \mathrm{H}$ 202 advanced oxidation process. Chemical Engineering Journal.
Harayama, S., and Rekik, M. (1989). Bacterial aromatic ring-cleavage enzymes are classified into two different gene families. Journal of Biological Chemistry, 264(26), 15328-15333.

Hirose, J., Kimura, N., Suyama, A., Kobayashi, A., Hayashida, S., and Furukawa, K. (1994). Functional and structural relationship of various extradiol aromatic ring-cleavage dioxygenases of Pseudomonas origin. FEMS Microbiology Letters, 118(3), 273-277.

Horvath, M., Bilitzky, L. and Huttner, J. (1985). Ozone. London, UK: Elsevier Science, pp. 259, 269-270.

Halmi MIE, Shukor MS, Johari WLW, Shukor MY (2014) Evaluation of several mathematical models for fitting the growth of the algae Dunaliella tertiolecta. Asian Journal of Plant Biology 2, 1-6.

Huang, L. (2013) Optimization of a new mathematical model for bacterial growth. Food Control32, 283-288. doi:10.1016/j.foodcont.2012.11.019.

International Union of Pure and Applied Chemistry (IUPAC) (1990). Glossary of Atmospheric Chemistry Terms (Recommendations 1990), Pure and Applied Chemistry, 62: 2167.

Ibarrolaza, A., Coppotelli, B.M., Del Panno, M.T., Donati, E.R., and Morelli, I.S. (2009). Dynamics of microbial community during bioremediation of phenanthrene and chromium (VI) contaminated soil microcosms. Biodegradation, 20(1), 95107.

International Agency for Research on Cancer, IARC (2010). Some non-heterocyclic polycyclic aromatic hydrocarbons and related exposures. IARC Monographs on the Evolution of Carcinogenic Risks to Humans, 92, 1-853.

Johnsen, A., and Karlson, U. (2005). PAH degradation capacity of soil microbial communities: Does it depend on PAH exposure? Microbial Ecology, 50(4), 488-495.

Johnsen AR, Binning PJ, Aamand J, Badawi N, Rosenbom AE (2013). The Gompertz function can coherently describe microbial mineralization of growthsustaining pesticides. Environmental Science and Technology47.

Knowles, G., Downing, A. L., \& Barrett, M. (1965). Determination of kinetic constants for nitrifying bacteria in mixed culture, with the aid of an 
electronic computer. Microbiology, 38, 263-278.

Kornegay, B. H., Andrews, J. F. (1968). Kinetics of fixed-film biological reactors. Journal (Water Pollution Control Federation), R460-R468.

Karamalidis, A.K., Evangelou, A.C., Karabika, E., Koukkou, A.I., Drains, C., andVoudrias, E.A. (2010). Laboratory scale bioremediation of petroleum contaminated soil by indigenous microorganisms and added Pseudomonas aeruginosastrain Spet. Bioresource Technology, 101(16), 65456552.

Keshavarzifard, M., and Zakaria, M.P. (2015). Polycyclic aromatic hydrocarbons contamination of surface sediments from Port Dickson, Malaysia: Distribution, sources and ecological risk assessment. Environmental

Forensics, 16(4), 322-332.

Khanna, S., Lal, B., Chandra, R., Rajam, S., and Bajpai, U. (1998).Enzymes and bioremediation. In Enzyme Chemistry: Impact and applications. Suckling, C.J., Gibson, C.L., and Pitt, A.K., Eds., Blackie Academic and Professional, Chapman and Hall, London, 240.

Kitano, H. (2002). Systems biology; a brief overview. Science, 295(5560), 16621664.

Kim, T.J., Lee, E.Y., Kim, Y.J., Cho, K.S., and Ryu, H.W. (2003). Degradation of polyaromatic hydrocarbons by Burkholderiacepacia 2A-12. World Journal of Microbiology and Biotechnology, 19(4), 411-417.

Kim, D.-J., Choi, J.-W., Choi, N.-C., Mahendran, B., \& Lee, C.-E. (2005). Modeling of growth kinetics for Pseudomonas spp. during benzene degradation. Applied microbiology and biotechnology, 69, 456-462.

Kimbara, K., Hashimoto, T., Fukuda, M., Koana, T., Takagi, M., Oishi, M., and Yano, K. (1989). Cloning and sequencing of two tandem genes involved in degradation of 2,3-dihydroxybiphenyl to benzoic acid in the polychlorinated biphenyldegrading soil bacterium Pseudomonas sp. strain KKS102. Journal of Bacteriology, 171(5), 2740-2747.

Kulkarni, M., Chaudhari, A. (2006). Biodegradation of $\mathrm{p}$-nitrophenol by $\mathrm{P}$. putida. Bioresource technology, 97, 982-988.

Loginova, E., Bartelt, N., Feibelman, P., \& McCarty, K. (2009). Factors influencing graphene growth on metal surfaces. New Journal of Physics, 11, 063046.

Lu, J., Guo, C., Zhang, M., Lu, G., and Dang, Z. (2014). Biodegradation of single pyrene and mixtures of pyrene by a fusant bacterial strain F14. International Biodeterioration Biodegradation, 87, 75-80.

Lundstedt, S., White, P.A., Lemieux, C.L., Lynes, K.D., Lambert, I.B., Öberg, L., and Tysklind, M. (2007). Sources, fate, and toxic hazards of oxygenated polycyclic aromatic hydrocarbons at PAH-contaminated sites. AMBIO: $A$ Journal of the Human Environment, 36(6), 475-485.

Maliszewska-K.B., and Smreczak, B. (2003). Habitat functions of agricultural soils as affected by heavy metals and polycyclic aromatic hydrocarbons contamination. Environment International, 28(8), 719-728.

Maliszewska, K.B. (1999). Sources, concentration, fate and effects of polycyclic aromatic hydrocarbons in the environment. Part A: PAHs in Air, Polish Journal of Environmental Studies, 8, 131-136.

Misenheimer, T.J., Anderson, R.F., Lagoda, A.A., Tyler, D.D. (1965). Production of 2-Ketogluconic Acid by Serratiamarcescens. Applied Microbiology.

Mishra, V., Lal, R., and Srinivasan. (2001). Enzymes and operons mediating xenobiotic degradation in bacteria. Critical Reviews in Microbiology, 27(2), 133-166.

Monod, J. (1949). The growth of bacterial cultures. Annual Review of Microbiology.

MohdRadzi, N.A.S., Abu Bakar, N.K., Emenike, C.U., and Abas, M.R. (2016). Polycyclic aromatic hydrocarbons: contamination level and risk assessment in urban 83 areas, Kuala Lumpur, Malaysia. Desalination and Water Treatment, 57(1), 171-190.

Moraes, B., Eduardo, T., and Sania, T.M (2009). Biodegradation of oil refinery residues using mixed-culture of microorganisms isolated from land farming. Brazilian Archives of Biology and Technology, 52(6), 1571-1578.

Madigan, M.T., J.M. Martinko and J. Parker (1998).Brock: Biología de los Microorganismos. Prentice Hall, España, 726. 
Mulchandani, A., Luong, J. (1989). Microbial inhibition kinetics revisited. Enzyme and microbial technology, 11, 66-73.

Mercurio, P., Burns, K. A., \& Negri, A. (2004). Testing the ecotoxicology of vegetable versus mineral based lubricating oils: 1 . Degradation rates using tropical marine microbes. Environmental pollution, 129, 165-173.

Nweke, C.N., Nwabanne, J.T., Igbokwe, P.K. (2014) Kinetics of batch anaerobic digestion of vegetable oil wastewater. Open Journal of Water Pollution and Treatment.

Nkeiruka, N.C., Tagbo NJ (2014) Continuous process design model simulation for the anaerobic digestion of vegetable oil wastewater. American Journal of Environmental Protection. 3, 209. doi:10.11648/j.ajep.20140305.11.

Nicholson, J.K., Holmes, E., Lindon, J.C., and Wilson, I.D. (2004). The challenges of modeling mammalian biocomplexity. Nature Biotechnology, 22, 1268-1274.

Nakai, C., Horiike, K., Kuramitsu, S., Kagamiyama, H., and Nozaki, M. (1990). Three isozymes of catechol 1,2dioxygenase (pyrocatechase), alpha alpha, alpha beta, and beta beta, from Pseudomonas arvilla C-1. Journal of Biological Chemistry, 265(2), 660-665.

Oa, S. W., and Lee, T. G. (2009). Investigation of soil pollution status for railroad depot. Railway Bulletin, 12(5), 788792.

Okpokwasili, G., Nweke, C. (2006). Microbial growth and substrate utilization kinetics. African Journal of Biotechnology, 5, 305-317.

Park, S.W., Lee, J.Y., Kim, K.J., Yang, J.S., and Baek, K. (2010). Alkaline enhanced separation of waste lubricant oils from railway contaminated soil. Separation Science and Technology, 45(12-13), 1988-1993.

Patri, M., Padmini, A., and Babu, P. P. (2010): Polycyclic aromatic hydrocarbons in air and their neurotoxic potency in association with oxidative stress: a brief perspective. Annals of Neuroscienc-es, 16(1), 22-30.

Poggi-Varaldo, H., Rodriguez-Vazquez, R., Fernandez-Villagomez, G., \& EsparzaGarcia, F. (1997). Inhibition of mesophilic solid-substrate anaerobic digestion by ammonia nitrogen. Applied microbiology and biotechnology.
Pereira, P.A.D.P., Lopes, W.A., Carvalho, L.S. da Rocha, G.O., de Carvalho Bahia, N., Loyola, J., and de Andrade, J.B. (2007). Atmospheric concentrations and dry deposition fluxes of particulate trace metals in Salvador, Bahia, Brazil. Atmospheric Environment, 41(36), 7837-7850.

Quintas, M. A., Brandao, T. R., \& Silva, C. L. (2007). Modelling colour changes during the caramelisation reaction. Journal of food engineering, 83, 483-491.

Raghuvanshi, S., Gupta, S., Babu, B.V. (2012). Application of biofilter system for removal of ethyl acetate: Column and kinetic studies

Rubio-Clemente, A., Torres-Palma, R.A., and Peñuela, G.A. (2014). Removal of polycyclic aromatic hydrocarbons in aqueous environment by chemical treatments: a review. Science of the Total Environment, 478, 201-225.

Ravindra, K., Sokhi, R., and Van Grieken, R. (2008). Atmospheric polycyclic aromatic hydrocarbons: source attribution, emission factors and regulation. Atmospheric Environment, 42(13), 2895-2921.

Richards, F.J. (1959). A flexible growths function for empirical use. Journal of Experimental Botany10, 290-300.

Salam, D. A., Suidan, M. T., \& Venosa, A. D. (2012). Effect of butylated hydroxytoluene (BHT) on the aerobic biodegradation of a model vegetable oil in aquatic media. Environmental science \& technology, 46, 6798-6805.

Sany, S.B.T., Hashim, R., Salleh, A., Rezayi, M., Mehdinia, A., and Safari, O. (2014). Polycyclic aromatic hydrocarbons in coastal sediment of Klang Strait, Malaysia: distribution pattern, risk assessment and sources. Plos one, 9, e94907.

Saifuddin N, Chua KH (2006) Biodegradation of lipid-rich wastewater by combination of microwave irradiation and lipase immobilized on chitosan. Biotechnology.

Spinelli, L., and Freitas, D.E. (2005).Bioremediation, Toxicity and Cell Damage in gasoline spills (Ph.D Thesis); Federal University of Rio Grande do Sul, Porto Alegre, Brazil.

Seo, J.S. (2006). Bacterial Proteomes and Metabolism of Aromatic Compounds. Ph.D. dissertation, University of Hawaii Manoa, USA. 
Seo, J.S., Keum, Y.S., and Li, Q.X. (2009). Bacterial degradation of aromatic compounds. International Journal of Environmental Research and Public Health, 6(1), 278-309.

Saravanan, P., Pakshirajan, K., \& Saha, P. (2008). Growth kinetics of an indigenous mixed microbial consortium during phenol degradation in a batch reactor. Bioresource technology, 99, 205-209.

Sandrin, T.R., and Maier, R.M. (2003). Impact of metals on the biodegradation of organic pollutants. Environmental Health Perspectives, 111(8), 1093.

Srogi, K. (2007). Monitoring of environmental exposure to polycyclic aromatic hydrocarbons: a review. Environmental Chemistry Letters, 5(4), 169-195.

Sabullah, M. K., Rahman, M., Ahmad, S., Sulaiman, M., Shukor, M., Shamaan, N. A., \& Shukor, M. (2016). Isolation and characterization of a molybdenumreducing and glyphosate-degrading Klebsiella oxytoca Saw-5 in soils from Sarawak. Agrivita, 38, 1.

Schröder, M., Müller, C., Posten, C., Deckwer, W. D., \& Hecht, V. (1997). Inhibition kinetics of phenol degradation from unstable steady-state data. Biotechnology and bioengineering, 54, 567-576.

Şeker, Ş., Beyenal, H., Salih, B., \& Tanyolac, A. (1997). Multi-substrate growth kinetics of Pseudomonas putida for phenol removal. Applied microbiology and biotechnology, 47, 610-614.

Stingley, R.L., Khan, A.A., and Cerniglia, C.E. (2004). Molecular characterization of a phenanthrene degradation pathway in Mycobacterium vanbaalenii PYR-1. Biochemical and Biophysical Research Communications, 322(1), 133-146.

Tavassoli, T., Mousavi, S., Shojaosadati, S., \& Salehizadeh, H. (2012). Asphaltene biodegradation using microorganisms isolated from oil samples. Fuel, 93.

Tao, X.Q., Lu, G.N., Dang, Z., Yang, C., and Yi, X.Y. (2007). A phenanthrene-degrading 85 strain Sphingomonas sp. GY2B isolated from contaminated soils. Process Biochemistry, 42(3), 401-408.

Thyrhaug, E., Zidek, K., Dostal, J., Bina, D. and Zigmantas, D. (2016). Exciton Structure and Energy Transfer in the FennaMatthews- Olson Complex. Journal Physical Chemistry Letters, 7(9): 16531660.
Tseng, M. M.C., Wayman, M. (1975). Kinetics of yeast growth: inhibition-threshold substrate concentrations. Canadian journal of microbiology.

Umar, Z.D., and Bashir, A. (2014): Assessment of potential health impacts on surface water sources in Northern Nigeria. International Journal of Environment, $3(2)$, 152-163. doi: $10.3126 /$ ije.v3i2.10523

Umar, Z.D., Aziz, N.A.A., Zulkefli, S.Z. and Muskhazli, M., (2016). Identification of phenanthrene and pyrene degrading bacteria from used engine oil contaminated soil. International Journal of Scientific and Engineering Research, 7, 680-686.

Umar, Z.D. (2017). Biodegradation of Phenanthrene and Pyrene using Bacteria isolated from used vehicle lubricant-contaminated soil. Doctoral Thesis (PhD). Published by Universiti Putra Malaysia Institutional repository (UPMIR). Pages 1-172. http://psasir.upm.edu.my/id/eprint/71 027/

Umar, Z.D., Aziz, N.A.A., Zulkifli, S.Z. and Muskhazli, M., (2017). Rapid biodegradation of PAHs using effective C. sakazakiimM045 (KT933253). MethodsX, 4, 104-117.

Umar, Z.D., Aziz, N.A.A., Zulkifli, S.Z. and Mustafa, M., (2018a). Efficiency of polycyclic aromatic hydrocarbons (PAHs) degrading consortium in resisting heavy metals during PAHs degradation. International Journal of Environment, 7(1): 14-27.

Umar, Z.D., Azwady, A.A.N, Zulkifli, S.Z., Muskhazli, M., (2018b). Effective Phenanthrene and Pyrene biodegradation using Enterobactersp. MM087 (KT933254) isolated from used engine oil contaminated soil. Egyptian Journal of Petroleum 27(3), 349-359.

Umar, Z.D., Mansir, A.Z., \&Riko, Y.Y., (2019). Compatibility and formulation of diesel degrading consortia using bacteria isolated from contaminated soil. Bayero Journal of Pure and Applied Sciences, 12(1), 199-208.

Umar, Z.D., Aminu, M., Yahaya, Y.R. (2020a). Survival response of Consortium isolates from diesel contaminated soil within Katsina State, Nigeria. International Journal of Environment. IJE-20-24 (Article in press).

Umar, Z.D., Aminu, M., Yahaya, Y.R. (2020b). Optimization of Diesel biodegrading 
conditions using Response Surface Methodology based on Central Composite Design. Polycyclic Aromatic Compounds. doi: 10.1080/10406638.2020.1823859.

Van Hamme, J.D., Singh, A., and Ward, O.P. (2003). Recent Advances in Petroleum Microbiology, Microbiology and Molecular Biology Review, 67(4), 649.

Vela, N., Martínez-Menchón, M., Navarro, G., Pérez-Lucas, G., and Navarro, S. (2012). Removal of polycyclic aromatic hydrocarbons from groundwater by heterogeneous photocatalysis under natural sunlight. Journal of Photochemistryand Photobiology A: Chemistry, 232, 32-40.

Wang, J., \& Wan, W. (2008). The effect of substrate concentration on biohydrogen production by using kinetic models. Science in China Series B: Chemistry.

Wong, F., Harnerb, T., Liua, Q.T., and Diamonda, M.L. (2004). Using experimental and forest soils to investigate the uptake of PAHs along urban-rural gradient. Environmental Pollution, 129(3), 387-398.

Yunusa, Y.R. and Umar, Z.D. (2021). Effective Microbial Bioremediation via the multi- omics Approach: An Overview of Trends, Problems and Prospects. UMYU Journal of Microbiology Research, 6(1), 127-145.

doi: https: / /doi.org/10.47430/ujmr.2161.02 2

Zhang, W.X., Bouwer, E.J., and Ball, W.P. (1998). Bioavailability of hydrophobic organic contaminants: Effects and implications of sorption-related mass transfer

on bioremediation. Groundwater Monitoring and Remediation, 18(1), 126-138.

Zhang, Z., Rengel, Z., Meney, K., Pantelic, L., and Tomanovic, R. (2011). Polynuclear aromatic hydrocarbons mediate cadmium toxicity to an emergent wetland species. Journal of Hazardous Materials, 189(1), 119-126.

Zwietering $\mathrm{MH}$, Jongenburger I, Rombouts $\mathrm{FM}$, Van'tRiet K (1990) Modeling of the bacterial growth curve. Applied and Environmental Microbiology. 